\title{
A taxonomic and phylogenetic review of the anhanguerid pterosaur group Coloborhynchinae and the new clade Tropeognathinae
}

\author{
Borja Holgado and Rodrigo V. Pêgas \\ Acta Palaeontologica Polonica 65 (4), 2020: 743-761 doi:https://doi.org/10.4202/app.00751.2020
}

Anhanguerids are a particular group of pterodactyloid pterosaurs, characterized mainly by their rostral sagittal crests, well laterally expanded jaw tips and enlarged anterior teeth. Due to the fragmentary nature of most known specimens, including holotypes, the taxonomy of the group has proved particularly difficult and controversial.

Coloborhynchinae is a recently proposed clade within the Anhangueridae, and was defined as the most inclusive clade containing Coloborhynchus clavirostris but not Anhanguera or Ludodactylus. Coloborhynchinae was originally thought to include Coloborhynchus, Uktenadactylus, and Siroccopteryx. Here we present a reassessment of the taxonomy and phylogeny of all proposed members of the Coloborhynchinae and Coloborhynchus complex, with new anatomical comparisons and a novel phylogenetic analysis. Several features allow us to establish that coloborhynchines were much more diverse than previously thought, englobing four genera and seven species: Aerodraco sedgwickii gen. et comb. nov., Coloborhynchus clavirostris, Nicorhynchus capito gen. et comb. nov., Nicorhynchus fluviferox gen. et comb. nov., Uktenadactylus rodriguesae sp. nov., and Uktenadactylus wadleighi. Nicorhynchus and Uktenadactylus are considered sister taxa, being distinct on the basis of several rostral characters. Although with a homoplastic flat rostrum surface, Siroccopteryx was recovered out of the Coloborhynchinae, as sister taxon of Tropeognathus , due to similarities on the palatal ridge (which is broad and deep, and starting at the same level) and the relatively stout teeth compared to other anhanguerids. Tropeognathus and Siroccopteryx are further related to the Australian taxa Ferrodraco and Mythunga, which are all grouped in a new clade: the Tropeognathinae. Our analysis suggests that morphological evolution within anhanguerids was quite more complex than previously thought, with coloborhynchines representing the oldest recorded lineage of Anhangueridae, which achieved a worldwide distribution at least from the Aptian to the Cenomanian.

Key words: Pterosauria, Pterodactyloidea, morphology, taxonomy, phylogeny, Cretaceous, USA, United Kingdom.

Borja Holgado [borja.holgado@mn.ufrj.br; borja.holgado@icp.cat],

Laboratory of Systematics and Taphonomy of Fossil Vertebrates, 
Departmento de Geologia e Paleontologia, Museu Nacional/Universidade

Federal do Rio de Janeiro, Quinta da Boa Vista s/n, São Cristóvão, 20940-040 Rio de Janeiro, RJ, Brazil; Institut Català de Paleontologia

Miquel Crusafont, $\mathrm{C} /$ de les Columnes, Universitat Autònoma de

Barcelona, E-08193 Cerdanyola del Vallès, Barcelona, Catalonia, Spain.

Rodrigo V. Pêgas [rodrigo.pegas@ hotmail.com], Laboratory of Vertebrate Paleontology and Animal

Behavior, Universidade Federal do ABC, Alameda da Universidade, s/n, Anchieta, 09606-045 São

Bernardo do Campo, SP, Brazil.

This is an open-access article distributed under the terms of the Creative Commons

Attribution License (for details please see creativecommons.org), which permits unrestricted use, distribution, and reproduction in any medium, provided the original author and source are credited.

\footnotetext{
FaF Full text $(1,965.5 \mathrm{kB})$

FDF Supplementary file $(1,027.5 \mathrm{kB})$
} 